\title{
Hepatitis C virus quantification in serum and saliva of HCV-infected patients
}

\author{
Gisele Barreto Lopes Menezes', Fernanda Albuquerque Pereira1, César Augusto Barros Duarte³, \\ Theomira Mauadie Azevedo Carmo', Hermes Pedreira da Silva Filho', Maria Alice Zarife², \\ Marco Aurélio Krieger ${ }^{3}$, Eliana Almeida Gomes Reis ${ }^{1}$, Mitermayer G Reis ${ }^{1 /+}$
}

${ }^{1}$ Laboratório de Patologia e Biologia Molecular-Fiocruz, Rua Waldemar Falcão 121, 40296-710 Salvador, BA, Brasil ²Laboratório Central de Saúde Pública Prof. Gonçalo Moniz, Salvador, BA, Brasil '3nstituto de Biologia Molecular do Paraná, Curitiba, PR, Brasil

The hepatitis C virus (HCV) can be detected in blood and other bodily fluids, such as saliva, semen and gastric juices. The aim of this study was to compare the HCV viral loads in the serum and saliva of infected patients. Twentynine patients with detectable HCV RNA in their serum and saliva were included in this study. The HCV viral loads were determined through quantitative real-time polymerase chain reactions. The median viral RNA levels were 5.78 $\log _{10}$ copies in the serum and $3.32 \log _{10}$ copies in the saliva. We observed that the salivary HCV viral load was significantly lower than the viral load in the serum. Further studies are required to understand the role of saliva in the diagnosis, management and potential transmission of $\mathrm{HCV}$.

Key words: HCV - HCV transmission - serum HCV load - salivary HCV load

The hepatitis $\mathrm{C}$ virus (HCV) is an important public health concern, affecting over 130 million individuals worldwide (Alter 2007). It is transmitted mainly through the parenteral route and sexual and vertical transmissions are considered to be rare. However, epidemiological studies suggest that the transmission routes of a large number of $\mathrm{HCV}$ infections are unknown (Heintges \& Wands 1997, Murphy et al. 2000).

Tests for the diagnosis and management of $\mathrm{HCV}$ infection include enzyme-linked immunosorbent assays (EIA) for the detection of anti-HCV antibodies, qualitative and quantitative tests to detect the HCV RNA and methods to determine the HCV genotypes (NHI 2002). A patient's response to antiviral therapy can be predicted by examining his or her HCV genotype (NHI 2002, Bacon $\&$ McHutchison 2007). While the detection of anti-HCV antibodies and HCV RNA in blood is the traditional method of viral surveillance, venipuncture is invasive, often painful and expensive. The use of saliva samples to diagnose HCV offers several potential advantages, such as minimal training requirements for sample collection and the use of a non-invasive collection technique. Such specimens are especially suitable for seroprevalence studies when blood samples are difficult to obtain (e.g., in intravenous drug users, children and haemophiliacs). Furthermore, the analysis of saliva can provide a cost-effective approach for the screening of large populations.

Many studies have documented the suitability of saliva samples for the diagnosis of HCV infections using EIA and real-time polymerase chain reaction (RT-

Financial support: CNPq (4003071/2004-6), PRONEX-08282/07

+ Corresponding author: miter@bahia.fiocruz.br

Received 13 May 2011

Accepted 12 April 2012
PCR) (McIntyre et al. 1996, Bello et al. 1998, Elsana et al. 1998, van Doornum et al. 2001, De Cock et al. 2004, Pastore et al. 2006, Wang et al. 2006, Gonzalez et al. 2008, Moorthy et al. 2008). Two studies in particular have demonstrated that the HCV viral load is higher in serum than in saliva in patients that are infected with HCV (Rey et al. 2001, Suzuki et al. 2005).

Abe and Inchauspe (1991) demonstrated that chimpanzees that were inoculated with HCV-containing saliva developed an infection and two reports have suggested that HCV is transmissible to humans via bite injuries (Dusheiko et al. 1990, Abe \& Inchauspe 1991, Figueiredo et al. 1994). The present study was designed to compare the HCV viral loads in the serum and saliva of $\mathrm{HCV}$-infected patients.

This cross-sectional study was performed from March-August of 2006. A total of 29 patients with chronic hepatitis $\mathrm{C}$ were selected among individuals who visited the Central Public Health Laboratory of Bahia, which is the only public laboratory that conducts the HCV-RNA detection test. Individuals with detectable HCV RNA in both their serum and saliva were included in the study and patients who had undergone antiviral therapy or had co-infections were excluded. None of the patients reported xerostomia or oral lesions.

Saliva and serum samples from 20 healthy donors were used as controls. The research protocol was approved by the Institutional Ethical Committee of Oswaldo Cruz Foundation-Bahia. Informed consent was obtained from all subjects who agreed to participate in this study.

The saliva and serum samples were collected from the patients after an eight-hour fasting period. Blood samples were collected in $10 \mathrm{~mL}$ Vacutainer tubes lacking anticoagulant (Becton Dickinson, San Jose, CA, USA) and centrifuged for $15 \mathrm{~min}$ at $3,000 \mathrm{rpm}$ to separate the sera. Non-stimulated whole saliva was collected through spitting without expectoration. The saliva and serum samples (approximately $3 \mathrm{~mL}$ each) were stored at $-70^{\circ} \mathrm{C}$ 
until use. We employed the Wright method, which uses a combination of eosin and methylene blue, to examine the saliva samples for the presence of blood and to rule out possible blood contamination (Dacie \& Lewis 2006).

HCV RNA was extracted from $200 \mu \mathrm{L}$ aliquots of each saliva and serum sample using the TRIzol LS reagent (Invitrogen, Life Technologies, Carlsbad, CA, USA) according to the manufacturer's instructions after digestion with $20 \mathrm{mg} / \mathrm{mL}$ proteinase K (Qiagen SA, Courtabouf, France) for $1 \mathrm{~h}$ at $56^{\circ} \mathrm{C}$. The HCV RNA was immediately transcribed into cDNA using random hexamers and reverse transcriptase (Invitrogen, Life Technologies, Carlsbad, CA, USA). The HCV RNA was detected using a nested RT-PCR technique that amplified a 251-bp fragment from the 5'-NC region of the HCV genome (Chan et al. 1992). The HCV genotype was determined through a restriction fragment length polymorphism analysis as previously described (Davidson et al. 1995).

The HCV viral load was determined through reverse transcription followed by a quantitative RT-PCR. The primers and probes that were labelled with the 5'-reporter dye 6-carboxyfluorescein (FAM) and the 3'-quencher dye 6-carboxy-N, N, N', N'-tetramethyl-rhodamine (TAMRA) were purchased from Applied Biosystems (Foster City, CA, USA). A reaction mixture containing $10 \mu \mathrm{M}$ of each primer (forward: 5'-CGGGAGAGC CATAGTGGT, reverse: 5'-CGCGACCCAACACTACTC) and $5 \mu \mathrm{M}$ of the fluorogenic probe (FAM-TGCGGAACCGGTGAGTACACC-TAMRA) was subjected to RT-PCR using the TaqMan system (Applied Biosystems, Foster City, CA, USA). A standard curve was generated using known concentrations of purified recombinant plasmid containing the HCV UTR region. Serial dilutions of this control plasmid ranging from 2.5 copies $/ \mathrm{mL}$ to 250,000 copies $/ \mathrm{ml}$ were prepared. RT-PCR was performed using the ABI Prism 7500 Sequence Detection System (Applied Biosystems, Foster City, CA, USA). The HCV viral load levels for all of the unknown samples were calculated through the extrapolation of the standard curve. The Amplicor ${ }^{\circledR} \mathrm{HCV}$ Monitor Test (Amplicor ${ }^{\circledR} \mathrm{HCV}$ Monitor, Roche, NJ, USA) was conducted according to the manufacturer's guidelines. The saliva samples were treated with proteinase $\mathrm{K}\left(20 \mathrm{mg} / \mathrm{mL}\right.$ for $1 \mathrm{~h}$ at $\left.56^{\circ} \mathrm{C}\right)$ before the HCV RNA was quantified. This test was used to confirm the HCV-RNA loads in the saliva and serum samples of all of the patients that were studied.

Statistical analyses were performed using Epi Info 2000 (CDC, Atlanta, GA, USA) and GraphPad Prism version 5.1 (GraphPad Software Incorporated, San Diego CA, 120 USA). Standard parametric and non-parametric statistical testing were applied as warranted. All of the tests were two-tailed and p-values $<0.05$ were considered to be significant.

The demographic and virologic characteristics of the 29 subjects are shown in Table. The study group was composed of 17 males $(58.6 \%)$ and 12 females $(41.3 \%)$ with a median age of 50 (interquartile range: 40-57 years). In the saliva and serum samples from the healthy donors, HCV-RNA was undetectable.

Among the $29 \mathrm{HCV}$-infected patients, 22 (75.8\%) were infected with genotype 1 , three $(10.3 \%)$ with genotype 2
TABLE

Demographic and virologic characteristics of the 29 subjects included in the study

\begin{tabular}{lcc}
\hline & \multicolumn{2}{c}{ Gender } \\
\cline { 2 - 3 } & $\begin{array}{c}\text { Male } \\
\text { Parameter }\end{array}$ & $\begin{array}{c}\text { Female } \\
(\mathrm{n}=17)\end{array}$ \\
\hline Age (years) & $(24-62)$ & $(37-62)$ \\
$\quad$ Median age (IQR) [n (\%)] $^{2} 50(44-57)$ & $51(41-58)$ \\
Viral load $^{a}$ & & \\
$\quad$ Saliva & 3.38 & 3.28 \\
Serum & 5.57 & 6.08 \\
p values (serum vs. saliva) & $<0.0001$ & $<0.0001$ \\
$95 \%$ confidence interval & \multicolumn{2}{c}{$1.90-2.96$} \\
Genotypes [n (\%)] & \multicolumn{2}{c}{} \\
1 & $13(76)$ & $9(75)$ \\
2 & $3(17.6)$ & $0(0)$ \\
3 & $1(6)$ & $3(25)$ \\
\hline
\end{tabular}

$a$ : median ( $\log _{10}$ copies); IQR: interquartile range.

and four $(13.7 \%)$ with genotype 3 . The saliva and serum samples from each patient were from the same genotypes. The data analysis did not demonstrate any significant differences between the HCV viral loads in the saliva and serum for the different HCV genotypes (Table).

A microscopic examination revealed no evidence of blood contamination in the saliva samples from the HCV-infected patients. Although HCV can enter the saliva via the gingival sulcus (Maticic et al. 2001), this cannot be the sole route because HCV RNA has been found in the saliva of edentate patients (Roy et al. 1998). An alternative mechanism for viral entry into saliva is active $\mathrm{HCV}$ replication in the salivary glands (Arrieta et al. 2001). This mechanism would explain the detection of different viral genotypes in the serum and saliva of individual patients (Roy et al. 1998) and the existence of patients with HCV RNA-negative serum and HCV RNA-positive saliva (Harle et al. 1993).

The presence of HCV RNA in human saliva may indicate that the saliva has been contaminated with blood particles, allowing for the transfer of HCV particles from the circulatory system. However, HCV RNA has been measured in the saliva of infected individuals independent of mucosal lesions and periodontal disease (Liou et al. 1992, Fabris et al. 1999, Hermida et al. 2002, Lins et al. 2005). Additionally, HCV could enter the saliva via peripheral blood mononuclear cells (PBMCs) (Roy et al. 1998, Fabris et al. 1999, Maticic et al. 2001); however, the presence of HCV RNA in PBMCs and saliva have not been closely correlated (Young et al. 1993). The detection of HCV RNA in saliva and the existence of a correlation between the viral load in saliva and other compartments have been demonstrated in previous studies (Mariette et al. 1995, Hermida et al. 2002, Eirea et al. 2005, Lins et al. 2005, Wang et al. 2006, Farias et al. 2010). 
A

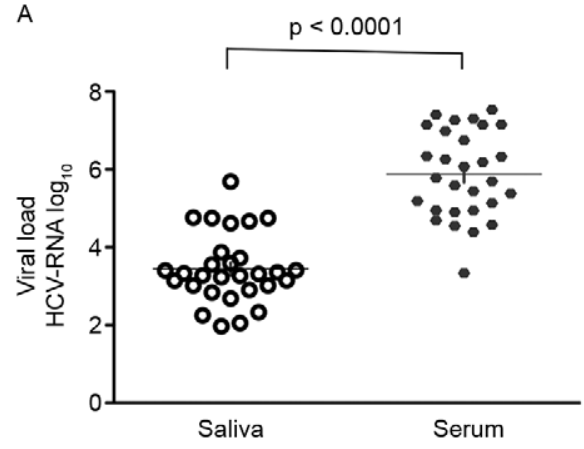

B

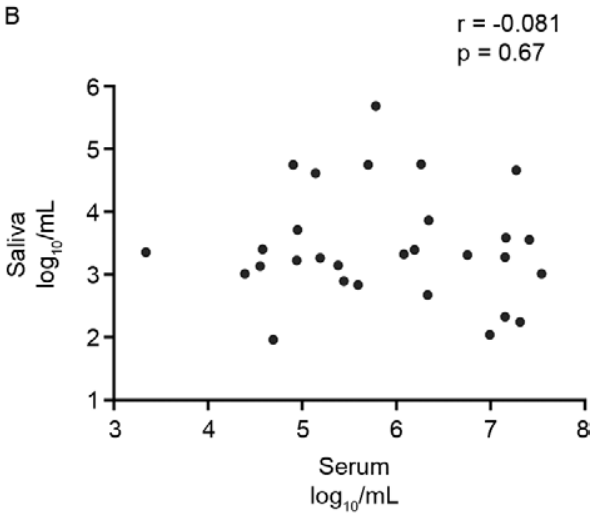

A: median of hepatitis C virus (HCV) RNA viral load in the serum and saliva in $\log _{10}\left(3.32 \log _{10}\right.$ copies $/ \mathrm{mL}$ in the saliva and $5.78 \log _{10}$ copies/ $\mathrm{mL}$ in the serum, $\mathrm{p}<0.0001,95 \%$ confidence interval 1.90-2.96); B: the Pearson test was used for testing the correlation between variables. No correlation is found between the HCV viral load in the saliva and serum of the patients (Pearson's $r=-0.081, p=0.67$ ). Statistical differences are highlighted in bold. Similar results were obtained using Amplicor methods (data not shown).

In this work, a quantitative PCR assay was used to determine HCV viral load levels in the saliva and serum of patients. The median viral RNA levels were $3.32 \log _{10}$ copies $\left(2.1 \times 10^{3}\right.$ copies $\left./ \mathrm{mL}\right)$ in the saliva and $5.78 \log _{10}$ copies $\left(1.21 \times 10^{6}\right.$ copies $\left./ \mathrm{mL}\right)$ in the serum $(\mathrm{p}<0.0001)$ (A in Figure). We did not use internal controls in the RTPCR, which would have detected the possible presence of PCR inhibitors. However, to reduce the probability of inhibition occurring during the RNA extractions, proteinase $\mathrm{K}\left(20 \mathrm{mg} / \mathrm{mL}\right.$ for $1 \mathrm{~h}$ at $\left.56^{\circ} \mathrm{C}\right)$ was used. Additionally, we used the same volumes of saliva and serum samples in all of the reactions to effectively demonstrate their contrasting viral loads.

No significant correlation was found between the $\mathrm{HCV}$ viral loads in the saliva and serum, most likely due to sample size (Pearson's $r=-0.081, p=0.67$ ) (B in Figure). All of the saliva and serum samples were tested using RT-PCR (Amplicor ${ }^{\circledR} \mathrm{HCV}$ Monitor, Roche, NJ, USA) and the results were similar to the results obtained (Pearson's $r=0.018, p=0.934$ ). These results are likely due to the small number of available samples.

Our study indicates that the viral loads in saliva are 100 times lower than those in serum. Katayama et al. (2004) investigated the minimal number of HCV RNA copies that is able to transmit HCV infection in chimpanzees using pre-acute-phase serum. They observed that serum containing $20 \mathrm{HCV}$ RNA copies was able to produce infection, suggesting that HCV can be transmitted by low virus levels. Abe and Inchauspe (1991) demonstrated the transmission of HCV through human saliva, but the number of viral copies was not determined. Epidemiological studies suggest that the infective capacity of HCV RNA virions in saliva is low (De Cock et al. 2004, Eirea et al. 2005). Further studies are required to investigate the infective potential of $\mathrm{HCV}$ positive saliva.

It is possible that a defence mechanism in the saliva may attenuate or abolish the infective potential of $\mathrm{HCV}$ RNA virions. Belec et al. (2003) observed that the saliva of HCV-infected individuals contains specific IgG and
IgA-neutralising antibodies that are directed against the E1 and E2 surface glycoproteins and may block viral adhesion to the host cell.

Although this study has some limitations due to the small number of available samples, we were able to provide information regarding the relationship between HCV viral loads in serum and saliva samples. However, further studies using larger sample sizes should be performed to confirm these results.

Other studies are also required to investigate the biological factors that are associated with HCV transmission. The elucidation of the mechanisms that are used by hosts to block HCV entry into the cell may contribute to the understanding of the role of saliva in HCV transmission.

\section{ACKNOWLEDGEMENTS}

To Vanja Ferreira and Lana Abreu, for technical support in collecting saliva and serum, Alan McBride and Jose Hagan, for his critical review of the manuscript, and Luciano Kalabric, for statistical support.

\section{REFERENCES}

Abe K, Inchauspe G 1991. Transmission of hepatitis C by saliva. Lancet 337: 248.

Alter MJ 2007. Epidemiology of hepatitis C virus infection. World $J$ Gastroenterol 13: 2436-2441.

Arrieta JJ, Rodriguez-Inigo E, Ortiz-Movilla N, Bartolome J, Pardo M, Manzarbeitia F, Oliva H, Macias DM, Carreno V 2001. In situ detection of hepatitis $\mathrm{C}$ virus RNA in salivary glands. Am J Pathol 158: 259-264.

Bacon BR, McHutchison JG 2007. Into the light: strategies for battling hepatitis C. Am J Manag Care 13 (Suppl. 12) S319-S326.

Belec L, Legoff J, Si-Mohamed A, Bloch F, Mbopi Keou FX, Becquart P, Matta M, Prazuck T, Petite JP, Gutmann L, Payan C 2003. Mucosal humoral immune response to hepatitis $C$ virus E1/E2 surface glycoproteins and HCV shedding in saliva and cervicovaginal fluids from chronically HCV-infected patients. J Hepatol 38: 833-842.

Bello PY, Pasquier C, Gourney P, Puel J, Izopet J 1998. Assessment of a hepatitis $\mathrm{C}$ virus antibody assay in saliva for epidemiological studies. Eur J Clin Microbiol Infect Dis 17: 570-572. 
Chan SW, McOmish F, Holmes EC, Dow B, Peutherer JF, Follett E, Yap PL, Simmonds P 1992. Analysis of a new hepatitis C virus type and its phylogenetic relationship to existing variants. $J$ Gen Virol 73: 1131-1141.

Dacie JV, Lewis SM 2006. Preparation and staining methods for blood and bone marrow films. In R Ross, Practical haematology, 10th ed., Churchill Livingstone, Edinburgh, p. 77-81.

Davidson F, Simmonds P, Ferguson JC, Jarvis LM, Dow BC, Follett EA, Seed CR, Krusius T, Lin C, Medgyesi GA 1995. Survey of major genotypes and subtypes of hepatitis $\mathrm{C}$ virus using RFLP of sequences amplified from the 5' non-coding region. $J$ Gen Virol 76: 1197-1204.

De Cock L, Hutse V, Verhaegen E, Quoilin S, Vandenberghe H, Vranckx R 2004. Detection of HCV antibodies in oral fluid. J Virol Methods 122: 179-183.

Dusheiko GM, Smith M, Scheuer PJ 1990. Hepatitis C virus transmitted by human bite. Lancet 336: 503-504.

Eirea M, Dios PD, Hermida M, Rodriguez I, Castro A, Ocampo A 2005. Detection of HCV-RNA in saliva of HIV-HCV coinfected patients. AIDS Res Hum Retroviruses 21: 1011-1015.

Elsana S, Sikuler E, Yaari A, Shemer-Avni Y, Abu-Shakra M, Buskila D, Katzman P, Naggan L, Margalith M 1998. HCV antibodies in saliva and urine. J Med Virol 55: 24-27.

Fabris P, Infantolino D, Biasin MR, Marchelle G, Venza E, Terribile WMV, Benedetti P, Tositti G, Manfrin V, de Lalla F 1999. High prevalence of HCV-RNA in the saliva cell fraction of patients with chronic hepatitis $\mathrm{C}$, but no evidence of $\mathrm{HCV}$ transmission among sexual partners. Infection 27: 86-91.

Farias A, Re V, Mengarelli S, Kremer L, Pisano MB, Allende L, Nicolas J, Elbarcha O, Contigiani M 2010. Detection of hepatitis C virus $(\mathrm{HCV})$ in body fluids from $\mathrm{HCV}$ monoinfected and $\mathrm{HCV} /$ HIV coinfected patients. Hepatogastroenterology 57: 300-304.

Figueiredo JF, Borges AS, Martinez R, Martinelli Ade L, Villanova MG, Covas DT, Passas AD 1994. Transmission of hepatitis C virus but not human immunodeficiency virus type 1 by a human bite. Clin Infect Dis 19: 546-547.

Gonzalez V, Martro E, Folch C, Esteve A, Matas L, Montoliu A, Grifols JR, Bolao F, Tural C, Muga R, Parry JV, Ausina V, Casabona J 2008. Detection of hepatitis C virus antibodies in oral fluid specimens for prevalence studies. Eur J Clin Microbiol Infect Dis 27: 121-126.

Harle JR, Swiader L, Disdier P, Gerolami V, Cartouzou G, Weiller J 1993. Identifying hepatitis $C$ virus by the gene amplification technique in the saliva of patients for whom the search is simultaneously negative in their serum: 9 cases. Rev Med Interne 14: 1005.

Heintges T, Wands JR 1997. Hepatitis C virus: epidemiology and transmission. Hepatology 26: 521-526.

Hermida M, Ferreiro MC, Barral S, Laredo R, Castro A, Diz Dios P 2002. Detection of HCV RNA in saliva of patients with hepatitis $\mathrm{C}$ virus infection by using a highly sensitive test. $J$ Virol Methods 101: 29-35.

Katayama K, Kumagai J, Komiya Y, Mizui M, Yugi H, Kishimoto S, Yamanaka R, Tamatsukuri S, Tomoguri T, Miyakawa Y, Tanaka
J, Yoshizawa H 2004. Titration of hepatitis C virus in chimpanzees for determining the copy number required for transmission. Intervirology 47: 57-64.

Lins L, Almeida H, Vitvisk L, Carmo T, Parana R, Reis MG 2005. Detection of hepatitis $\mathrm{C}$ virus RNA in saliva is not related to oral health status or viral load. J Med Virol 77: 216-220.

Liou TC, Chang TT, Young KC, Lin XZ, Lin CY, Wu HL 1992. Detection of HCV RNA in saliva, urine, seminal fluid and ascites. J Med Virol 37: 197-202.

Mariette X, Loiseau P, Morinet F 1995. Hepatitis C virus in saliva. Ann Intern Med 122: 556.

Maticic M, Poljak M, Kramar B, Seme K, Brinovec V, Meglic-Volkar J, Zakotnik B, Skaleric U 2001. Detection of hepatitis C virus RNA from gingival crevicular fluid and its relation to virus presence in saliva. $J$ Periodontol 72: 11-16.

McIntyre PG, Laszlo J, Appleyard K, Ogden GR 1996. Modified enzyme immunoassay to detect hepatitis $\mathrm{C}$ virus antibodies in oral fluid. Eur J Clin Microbiol Infect Dis 15: 882-884.

Moorthy M, Daniel HD, Kurian G, Abraham P 2008. An evaluation of saliva as an alternative to plasma for the detection of hepatitis $\mathrm{C}$ virus antibodies. Indian J Med Microbiol 26: 327-332.

Murphy EL, Bryzman SM, Glynn SA, Ameti DI, Thomson RA, Williams AE, Nass CC, Ownby HE, Schreiber GB, Kong F, Neal KR, Nemo GJ 2000. Risk factors for hepatitis C virus infection in United States blood donors. NHLBI Retrovirus Epidemiology Donor Study (REDS). Hepatology 31: 756-762.

NHI - National Institutes of Health 2002. NIH Consensus Statement on Management of Hepatitis C: 2002. Available from: doh.state. fl.us/disease_ctrl/aids/hep/hepatitis_c_consensus.pdf.

Pastore L, Fiore JR, Tateo M, De Benedittis M, Petruzzi M, Casalino C, Genchi C, Lo Muzio L, Angarano G, Serpico R 2006. Detection of hepatitis $\mathrm{C}$ virus-RNA in saliva from chronically HCVinfected patients. Int J Immunopathol Pharmacol 19: 217-224.

Rey D, Fritsch S, Schmitt C, Meyer P, Lang JM, Stoll-Keller F 2001. Quantitation of hepatitis C virus RNA in saliva and serum of patients coinfected with HCV and human immunodeficiency virus. J Med Virol 63: 117-119.

Roy KM, Bagg J, McCarron B, Good T, Cameron S, Pithie A 1998. Predominance of $\mathrm{HCV}$ type $2 \mathrm{~A}$ in saliva from intravenous drug users. J Med Virol 54: 271-275.

Suzuki T, Omata K, Satoh T, Miyasaka T, Arai C, Maeda M, Matsuno T, Miyamura T 2005. Quantitative detection of hepatitis $C$ virus (HCV) RNA in saliva and gingival crevicular fluid of HCV-infected patients. J Clin Microbiol 43: 4413-4417.

van Doornum GJ, Lodder A, Buimer M, van Ameijden EJ, Bruisten $\mathrm{S} 2001$. Evaluation of hepatitis $\mathrm{C}$ antibody testing in saliva specimens collected by two different systems in comparison with HCV antibody and HCV RNA in serum. J Med Virol 64: 13-20.

Wang CC, Morishima C, Chung M, Engelberg R, Krantz E, Krows M, Sullivan DG, Gretch DR, Corey L 2006. High serum hepatitis $\mathrm{C}$ virus (HCV) RNA load predicts the presence of HCV RNA in saliva from individuals with chronic and acute HCV infection. J Infect Dis 193: 672-676.

Young KC, Chang TT, Liou TC, Wu HL 1993. Detection of hepatitis $\mathrm{C}$ virus RNA in peripheral blood mononuclear cells and in saliva. J Med Virol 41: 55-60. 